\title{
Contradiction Between Supply and Demand of Logistics Talents Training and Teaching Reform in China
}

\author{
Zhong Zheng ${ }^{1,2^{*}}$ Liwei $^{\mathrm{Li}^{1}}$ Ganglan Wei ${ }^{1}$ \\ ${ }^{1}$ College of Transportation, Nanning University, Nanning, China \\ ${ }^{2}$ College of Administration and Management, King Mongkut's Institute of Technology Ladkrabang, KMITL, Bangkok, \\ Thailand \\ *Corresponding author. Email: 523201940@qq.com
}

\begin{abstract}
With the continuous emergence of new technologies, new models and new methods, new requirements have been put forward for the training of logistics talents. This paper makes a comprehensive analysis of the supply and demand of logistics talents in China, combines the demand of logistics talents in the new era and new economic environment. This paper studies the contradiction between supply and demand from the aspects of quantity, quality, industry structure and new economic environment of logistics talents. On this basis, this paper studies the strategies to alleviate the contradiction between supply and demand of logistics talents, and puts forward the reform strategy of logistics construction and development of logistics specialty, in order to provide beneficial exploration for the construction and development of logistics major.
\end{abstract}

Keywords: Logistics talents, Supply and demand contradiction, Talent training.

\section{INTRODUCTION}

China's logistics industry is in a new stage of development with transformation and upgrading as the main line, which has gradually changed from pursuing the growth of scale and quantity to improving the quality benefit, from cost-driven to efficiency improvement and innovation driven [1]. At the same time, with the rise of a new round of revolution of science and technology, the traditional logistics industry by introducing new technology, new mode and new concept, new mechanism, making the logistics industry closely integrated with the Internet technology, industrial revolution in-depth and sustained development of the global value chain and industrial chain system constantly refactoring, which provide important opportunities for development for the logistics personnel, at the same time, it puts forward a new challenge for the logistics personnel training. Although the quantity and quality of logistics talents in China are constantly improving, the disconnection between talent training and enterprise demand is still serious. It is necessary and urgent to study the training strategy of logistics talents under the new environment.

\section{ANALYSIS OF THE CURRENT SITUATION OF LOGISTICS TALENT SUPPLY IN CHINA}

In terms of quantity of supply, the training of logistics professionals in China has developed rapidly in the past ten years, and the achievements have been remarkable. China's logistics education began in the 21st century [2]. In 2001, Beijing Institute of Materials and Materials took the lead in opening logistics management major in China. Over the past 10 years, more than 500 institutions of higher learning in China have opened logistics-related specialties including logistics management, logistics engineering and procurement management. The number of institutions of higher learning with logistics majors and enrollment nationwide is 551 in 2016, with 19 new institutions in 2016.The number of logistics-related majors enrolled in 2017 reached 570.Detailed data are shown in Table 1. 
Table 1. Statistical table of logistics related majors

\begin{tabular}{|c|c|c|c|c|c|}
\hline \multirow{2}{*}{ Project } & \multirow{2}{*}{$\begin{array}{l}\text { Number of } \\
\text { Institutions }\end{array}$} & \multicolumn{5}{|c|}{ Professional Placement } \\
\cline { 5 - 6 } & & Sum & $\begin{array}{c}\text { Physical distribution } \\
\text { management }\end{array}$ & $\begin{array}{c}\text { Logistics } \\
\text { engineering }\end{array}$ & $\begin{array}{c}\text { Purchasing } \\
\text { management }\end{array}$ \\
\hline Enrolment in 2016 & 551 & 598 & 479 & 114 & 5 \\
\hline New approvals in 2016 & 19 & 24 & 16 & 6 & 2 \\
\hline Enrolment in 2017 & 570 & 622 & 495 & 120 & 7 \\
\hline
\end{tabular}

In terms of quality of supply, under the guidance of the National Logistics Management Professional Steering Committee, colleges and universities have established a systematic professional training system in the aspects of curriculum design, practical links and training methods. The courses offered in most colleges and universities include Introduction to Logistics, Warehouse Management, Transportation Management, Distribution Center Planning and Design, Third Party Logistics Management, International Logistics, Logistics Information System, Logistics Cost Management, Supply Chain Management and Logistics Professional English, etc. Cultivate a large number of solid logistics talents for China [3]. According to the "2019 Employment Blue Book" released by MyCOS, the employment satisfaction of logistics majors and the jobs they are engaged in are generally relatively ideal.

In terms of the results of Talent supply, according to the 2016 China College Student Employment Report by the Match Research Institute, the highest employment rate six months after graduation in 2015 is in logistics management, Employment rate 96.6percent. Meanwhile, logistics professional employment mainly goes to small and medium-sized private enterprises. After graduation, the promotion first-line job list promotion is faster. Research shows that due to the rapid development of logistics industry, the demand for talents in the industry is strong, the promotion cycle of logistics graduates is short, and the development prospect is good.

\section{ANALYSIS OF THE CURRENT SITUATION OF LOGISTICS TALENT DEMAND IN CHINA}

In recent years, the rapid development and transformation and upgrading of logistics industry have formed a huge demand for logistics talents, with the development of "Belt and Road" strategy, especially the continuous promotion of logistics channels such as "China-Singapore (Chongqing) Demonstration Initiative on Strategic Connectivity "," New Land-Sea Channel " and "Regional Comprehensive Economic Partnership
(RECP) ", higher demand has been put forward for the training of logistics talents. At the same time, with the application of new models, new methods and new technologies in the physical field, the current logistics industry puts forward higher demand for the comprehensive ability of talents.

\subsection{China's Demand for Logistics Professionals from the Perspective of Industry Demand}

The counterpart major of logistics graduates is logistics position, including logistics related industry legal person units and individual industrial and commercial employees engaged in logistics activities, as well as industrial, wholesale and retail industry legal person units of logistics positions. By the end of 2016, China's logistics workforce was 50.12 million, up 0.6 percent from 2015, accounting for 6.5 percent of the

country's workforce, according to the China Joint Logistics and Procurement Commission. Among them, the number of employees in logistics related industries in China was 10.08 million, an increase of 4.7 percent the number of individual industrial and commercial workers engaged in logistics activities is 27.94 million; over the previous year, a growth rate of 1.5 percentage points higher than that of urban employment; Industrial, wholesale and retail industries, such as corporate units of logistics positions of 12.11 million employees. Further subdividing the personnel of logistics related industries, and finding that the road transportation, express logistics and railway transportation account for a large proportion, As shown in Figure 1.

With the sustained development of China's economy, the total amount of social logistics has increased rapidly, and the demand for logistics talents in various industries will continue to increase, especially with the continuous popularization of e-commerce and the maturity of new retailing, the demand for talents in express logistics industry will increase rapidly. 


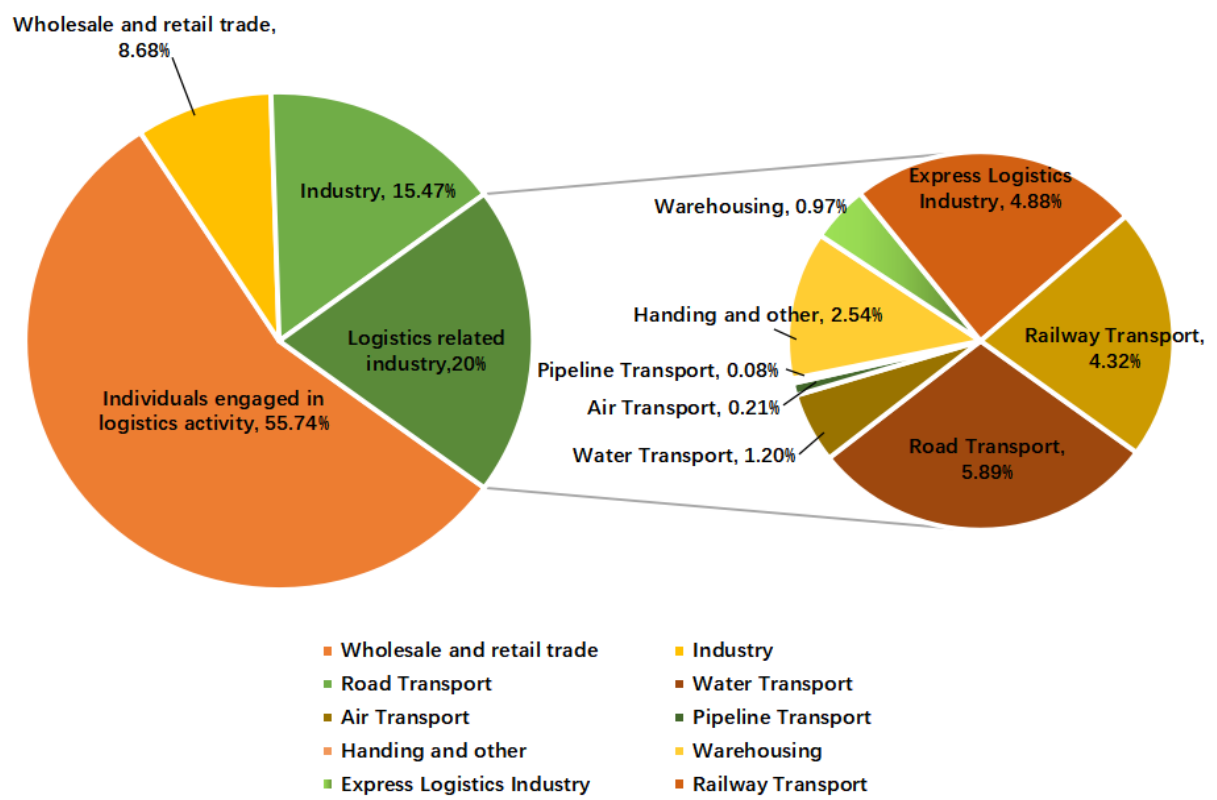

Figure 1 Distribution of Logistics Industry Employees in China.

\subsection{Analyzing the Needs of Talents at All Levels of Logistics in Terms of Quality Requirements}

Logistics talents can be divided into three levels according to the level of talent quality: high-level, intermediate and primary logistics talents [3-5]. Because logistics is a management work which includes the functions of purchasing, warehousing, transportation, packaging, international trade, finance, computer and so on, logistics talents show a certain degree of comprehensiveness. Senior logistics personnel need to have a strong comprehensive ability to understand both logistics expertise and other professional skills involved in the position, therefore, the senior logistics talents most needed by modern enterprises at present need strong strategic judgment ability, management ability and insight, and can easily carry out macro-control on all links. They focus on the overall goal planning of enterprise logistics and play a leading role. Intermediate logistics personnel need to have a certain comprehensive ability, intermediate logistics personnel focus on the implementation of enterprise plans, and specific management in specific areas, requiring proficiency in the operation of various links, including warehousing management, logistics operation, procurement work, transportation management and other aspects of the operation. And the effective coordination of logistics links, to ensure the rationalization of the logistics system, scientific operation. Junior logistics personnel and general operators are the implementation of the logistics system, mainly responsible for specific logistics operations, including incoming and outgoing operations, cargo loading, sorting, distribution, etc. This type of work is biased towards manual labor, which requires low cultural quality of workers, requires the use of simple office software, and has good operational skills, communication skills and teamwork skills [3]. According to the investigation and comprehensive analysis, through the full investigation, this paper analyzes the ability, knowledge and specific corresponding positions required at different levels of logistics as shown in Table 2.

Aiming at the data survey of Changfeng Vocational Education Research Institute, in 2016, the number of primary, intermediate and senior posts in the logistics industry in China accounted for 69\%, 25\% and 6\% of the total number, respectively. The demand for primary posts accounted for more than half of the total number, while the demand for middle and senior posts was relatively small.

According to the analysis of the demand for ability and knowledge of talents at all levels of logistics, at present, the training of talents in Chinese colleges and universities should take the middle and senior logistics talents as the starting point, and require students to master solid professional knowledge and cultivate students' comprehensive application ability. 
Table 2. Knowledge and post of different levels of logistics

\begin{tabular}{|c|c|c|c|}
\hline $\begin{array}{c}\text { Administrative } \\
\text { Levels }\end{array}$ & Capacity & Knowledge & Station \\
\hline Junior & $\begin{array}{l}\text { Have a certain knowledge of logistics, } \\
\text { can use simple office software, and } \\
\text { have good operational skills, } \\
\text { communication skills and teamwork } \\
\text { skills }\end{array}$ & $\begin{array}{l}\text { Word, excel and other kinds of } \\
\text { office software use, all kinds of } \\
\text { logistics machinery and equipment } \\
\text { operation, basic logistics } \\
\text { knowledge }\end{array}$ & $\begin{array}{l}\text { Buyer, Trucker, Distributor, } \\
\text { Delivery, Loading, } \\
\text { Documentary, Custodian, } \\
\text { Courier, Operator }\end{array}$ \\
\hline Intermediate & $\begin{array}{l}\text { Have a certain comprehensive ability, } \\
\text { proficient in including warehouse } \\
\text { management, logistics operation, } \\
\text { procurement work, transportation } \\
\text { management and other aspects of the } \\
\text { operation, have a good coordination } \\
\text { management ability and execution }\end{array}$ & $\begin{array}{l}\text { Warehousing, Transportation, } \\
\text { Distribution, Logistics Costs, } \\
\text { International Trade and Settlement, } \\
\text { Logistics Informatization, Quality } \\
\text { Management, Production } \\
\text { Operation Management, Insurance, } \\
\text { Law }\end{array}$ & $\begin{array}{lr}\text { Marine } & \text { Operations, Air } \\
\text { Operations, } & \text { Logistics } \\
\text { Scheduling, } & \text { Logistics } \\
\text { Assistant, } & \text { Warehousing } \\
\text { Manager, } & \text { Warehousing } \\
\text { Supervisor, } & \text { Operations } \\
\text { Manager and } & \text { Operations } \\
\text { Supervisor } & \\
\end{array}$ \\
\hline Senior & $\begin{array}{l}\text { Strong comprehensive ability, } \\
\text { knowledge of logistics and other } \\
\text { professional skills, strong strategic } \\
\text { judgment, management, resource } \\
\text { integration and insight }\end{array}$ & $\begin{array}{l}\text { Supply chain management, ERP } \\
\text { management, big data analysis, } \\
\text { business diagnostics and } \\
\text { consulting, facility layout and } \\
\text { planning, supply chain/logistics } \\
\text { solutions, strategic management }\end{array}$ & $\begin{array}{l}\text { Senior Logistics } \begin{array}{l}\text { Manager, } \\
\text { Senior }\end{array} \text { Logistics } \\
\text { Supervisor, r Logistics } \\
\text { Director, Supply Chain } \\
\text { Director and Operations } \\
\text { Director }\end{array}$ \\
\hline
\end{tabular}

\subsection{Analyzing the Demand of Logistics Talents from the Aspect of Talent Type}

China's logistics industry talent demand can be divided into enterprise logistics talent, logistics enterprise talent, logistics planning and consulting talent, export-oriented international logistics talent and scientific research and teaching logistics talent [4]. The main demand of enterprise logistics talents is produced in manufacturing industry, and enterprise logistics talents are mainly engaged in production logistics management. The specific contents of the work are in-plant logistics management, procurement logistics management and sales logistics management, which is an important guarantee for the normal operation of enterprise logistics. The demand for talents in logistics enterprises is mainly generated by third party logistics enterprises and enterprises engaged in logistics related affairs, at present, there are more than 300000 corporate units engaged in logistics activities in China. With the continuous development of e-commerce and the popularization of logistics service outsourcing, logistics enterprises urgently need a large number of logistics talents. Logistics planning and consulting talents are high-quality compound logistics talents, which need strong logistics planning layout, diagnosis and optimization ability. With the increasingly prominent role of logistics cost reduction and efficiency, logistics planning and consulting personnel are also increasingly scarce. Now in the environment of global economic integration, after the "Belt and Road" strategy was put forward, it provides unprecedented opportunities for the development of international logistics, so China urgently needs a large number of export-oriented international logistics talents who are familiar with the knowledge and skills of import and export trade, customs business, supply chain management and so on. At present, the research of logistics theory in China is still in the development stage, many theoretical basis and practical problems need to be further studied and solved. The breakthrough of logistics theory and the innovation of logistics application technology need the strong support of high quality and strong ability logistics scientific research talents.

\section{ANALYSIS OF THE CONTRADICTION BETWEEN SUPPLY AND DEMAND OF LOGISTICS TALENTS}

Although China's logistics personnel training and has formed a different level of system, the number of training is growing rapidly, but the problem of talent training and enterprise demand disconnect still exists, Through the investigation and discussion of the enterprise, it is found that the graduates under the training mode of logistics specialty at the present stage do not match the needs of the enterprise in terms of comprehensive skills and quality, and cannot meet the needs of the society, the contradiction between supply and demand of logistics talents in China is mainly reflected in the following aspects.

\subsection{Disconnection between Talent Training System and Industry Demand}

At present, the homogeneity of logistics specialty in most universities in China is serious, comprehensive analysis of major colleges and universities professional training programs, most colleges and universities in the beginning of the logistics major lack of consideration of their own positioning and from the training objectives, teaching plans, curriculum design and so on [4-6]. As a result, the logistics majors in colleges and universities are 
much the same, lack of characteristics, education and industry disjointed, theory and practice disjointed, cannot really connect with the local industrial needs [7].

\subsection{Supply Quality of Logistics Talents is not High}

At present, the logistics students trained in Chinese colleges and universities basically have solid professional knowledge, but the overall comprehensive ability is poor, mainly reflected in two aspects, on the one hand, lack of macro and systematic thinking, it is difficult to support their development to a higher level. The causes of such problems are as follows: Firstly, curriculum design, theoretical teaching and practice of the uneven distribution of hours; Secondly, the school laboratory condition is not good, the student lacks the good practice environment and the platform; Thirdly, the reasons for the greater impact are that the cooperation between schools and enterprises is not deep enough, and the practical activities of students are not solid [5, 8, 9]. At present, although most colleges and universities carry out cooperation between schools and enterprises, the cooperation between schools and enterprises generally stays at the level of signing cooperation agreements and listing each other, and has not yet carried out a long-term mechanism for the cooperation between schools and enterprises, and lacks a deep and cooperation project between schools and enterprises. At the same time, although many schools arrange student job placement practice, but the specific post is flow work, students in the process of job placement practice cannot go deep, systematic school logistics.

\subsection{Logistics Talent Training Cannot Keep Up with Industrial Development}

With the development of big data, internet of things, artificial intelligence, AR/VR and other information technologies, as well as the breakthrough of unmanned warehouse, unmanned aerial vehicle, unmanned vehicle and other technologies, as well as the emergence of new logistics models such as shared logistics, crowdsourcing logistics, $\mathrm{O} 2 \mathrm{O}$, new retail, it is necessary to train students who can apply new technologies and tools flexibly, and to cultivate students with innovative consciousness [9]. It is necessary to train talents with cost control consciousness and cross-border integration. When the implementation equipment of logistics specialty lags behind the development of industry at present, it is not conducive to promoting students' innovation and entrepreneurship, and restricts the development of logistics industry.

\subsection{The Mismatch between Talent Structure and Industry Demand}

Logistics is a subject with strong application, which is closely related to practical operation ability, At the same time, from the point of view of logistics demand, the biggest demand in China's logistics industry is primary logistics staff. However, according to the characteristics of logistics posts, the requirements of primary logistics staff to master the knowledge is not high, high school and even junior high school graduates can better master and do a good job of the corresponding technology. Therefore, the training of logistics talents in colleges and universities should be oriented to the training of intermediate and senior logistics talents, according to the investigation, although graduates of colleges and universities will start from the first line of operation, but the promotion is faster, basically will not stay in the for a long time $[9,10]$. At present, logistics students trained in China only have basic professional knowledge and lack more macro and comprehensive ability, which is not conducive to the development of middle and senior logistics talents, which is also the reason for the shortage of intermediate and senior logistics talents in China.

\section{RESEARCH ON TRAINING COUNTERMEASURES OF LOGISTICS TALENTS IN NEW ENVIRONMENT}

\subsection{Promoting Education and Teaching Reform}

\subsubsection{Changing Educational Ideas}

It is an important problem for logistics specialty to study how to combine the resources of colleges and universities to create applied logistics talents with their own characteristics and professional skills. Combining with the characteristics of regional industry, this paper explores a new teaching idea $[11,12]$. On the basis of following the systematization and specialization of logistics, we should make teaching plan around students' professional ability, change the traditional spoon-feeding teaching idea, take the knowledge and ability of post demand as the core, realize the effective transformation of students from knowledge-ability-post, optimize according to the integration of enterprise work flow and curriculum, reform traditional teaching methods, and pay more attention to the cultivation of technical knowledge, innovation ability and systematic thinking [13]. Comprehensive analysis and scientific prediction of the current and future supply and demand of logistics talents in the region, combined with regional economic characteristics and industrial development needs to be targeted to reconstruct the logistics talent training objectives, talent training system and curriculum system, 
to ensure the seamless docking between school training and social needs $[14,15]$.

\subsubsection{Innovative Teaching Methods}

With the deepening of information technology to education, under the impetus of the Internet and big data, MOOC, new teaching forms such as micro-class, SPOC, live course, flipping subject and so on, the logistics specialty should innovate the teaching method, should introduce $\mathrm{AR} / \mathrm{VR}$, big data and other information systems to optimize the teaching experiment environment and create a good teaching platform, so as to develop individualized, intelligent and perceptual wisdom education, use new technology to stimulate learning motivation, enhance learning experience and create immersive learning, so as to better enable students to accept knowledge and increase their skills [16-20].

\subsubsection{Innovative Teaching Methods}

In terms of teaching methods, we should actively promote the "project-oriented, task-driven" teaching method, take the curriculum project as the carrier, change the classroom mode centered on teachers and teaching materials, construct the classroom with students as the main body, follow the characteristics of logistics development, introduce new open and innovative teaching methods such as scene teaching, social research, learning while doing, fully arouse students' learning enthusiasm, stimulate students' innovative consciousness and inner potential, and constantly improve students' logistics professional skills and innovative application skills [21].

\subsection{Strengthening School-Enterprise Cooperation}

\subsubsection{Build Platform, School-enterprise Co- construction Project Research Center Model}

School-enterprise cooperation is the main platform and carrier of talent training, logistics talent training cannot be closed training, must be achieved through school-enterprise cooperation. At the same time, scientific research is an important tool to absorb industry and enterprises and even government resources and support teaching. Without scientific research as the support of serving local governments and enterprises, it is difficult for schools to attract the attention of enterprises and government attention. Therefore, it is necessary to introduce advanced logistics enterprises, build research institutes with logistics enterprises, take the practical problems in the operation of logistics industry and logistics enterprises as projects, and set up teams to carry out research [16]. And apply the research results to enterprises, conducive to the development of local logistics industry. At the same time, through the development of joint projects, on the one hand, improve the scientific research level of the teacher team, on the other hand, the project can be subdivided into subprojects, so that students can form teams to participate in the operation of the project and can train the student's application skill and the innovation ability very well.

\subsubsection{Introduction of Business Processes into Courses}

One of the obvious characteristics of logistics specialty is the strong practicality. Based on the specialty characteristics, we can consider introducing the real logistics business into the school and combining the training base of the school with the logistics work site of the enterprise. For example, introducing the specific business of large supply chain management company, it can provide local large e-commerce enterprises and retail enterprises with receiving, warehousing, packing and shipping business, students carry out actual operations in the form of groups, and professional teachers take turns in class management, Core courses such as "Warehouse Management", "Distribution Management", "Electronic Commerce", "Logistics Informatization", "Logistics Machinery and equipment" and "Facility Planning and layout" in logistics major can be studied while practicing, and the enterprise management and assessment models such as $5 \mathrm{~S}$ management, performance appraisal and target management can be introduced into the training center to combine teaching process with production process to improve the professional skills and professional accomplishment of logistics students.

\subsubsection{A Modern Apprenticeship Model}

In order to create a wider development platform for students, schools should cooperate with excellent enterprises of different types of logistics, cooperate with enterprises in accordance with the development wishes of different students and in accordance with the quasimodern apprenticeship system, select students willing to participate in apprenticeship teaching from the lower grade students, study talent training programs, develop courses and teaching materials, design teaching links, organize assessment and evaluation, appoint excellent employees as students' corporate mentors, take charge of students' courses and work contents during the enterprise period, and extend teaching space from school to school, The "flexible" and "individualized" logistics teaching mode in which schools and enterprises participate together, students not only complete the systematic professional courses, but also receive the training of various modules of the enterprise, so as to better improve the students' professional skills and comprehensive quality. 


\section{CONCLUSION}

This paper analyses the current situation of logistics personnel training in China and the current situation of logistics personnel supply and demand, deeply studies the contradiction between supply and demand of logistics personnel in China, combines the new era demand and new mode to bring about changes in logistics industry, and studies the reform of talent training through education and teaching reform, school-enterprise cooperation, effectively alleviates the contradiction between supply and demand of logistics talents in China, and finally provides high-quality applied talents for the rapid development of logistics industry in China.

\section{AUTHORS' CONTRIBUTIONS}

This paper from two dimensions of quality and quantity to contrast China logistics talent supply and demand, objectively reflected the contradiction between supply and demand of China's logistics talent, further reveals the current situation of logistics personnel training and highlight the necessity of reform, on this basis, the paper tries to explore how to integrate resources and innovate education mode to solve the corresponding problems, the paper has good answered to "cultivating what kind of person? And how to train talents ", the paper provides some ideas for the training of logistics talents in China under the background of rapid economic development.

\section{ACKNOWLEDGMENTS}

This project is supported by Guangxi philosophy and social science planning research project (17FJY014), Guangxi young and middle-aged teacher's basic ability enhancement project (2018KY0744) and teaching reform project of Nanning University (2018XJJG22).

\section{REFERENCES}

[1] Gan Weihua, Zhang Tingting, Zhu Yuwei. On RFID application in the information system of rail logistics center[J]. International Journal of Education and Management Engineering, 2013, 3(2): 52-58. DOI: https://doi.org/10.5815/ijeme. 2013.02.09

[2] Yu Lina. Research on the "Cooperative Education" model cultivating in higher vocational education[J]. International Journal of Education and Management Engineering, 2012, 2(1): 521-524. DOI: https:// doi.org/ 10.5815/ ijeme. 2012.01.06

[3] Wang Y, et al. Discussion on the training mode of undergraduate talents in logistics management specialty of national colleges and universities[J]. New Situation Education and Teaching Forum, 2015, (49): 145-146. "In Chinese". DOI: https://doi.org/10.3969/j.issn.1674-

9324.2015.49.062

[4] Li Yang. A study on the cultivation of applied logistics talents under belt and road strategy[J]. Logistics Engineering and Management, 2015, (8): 123-124. "In Chinese". DOI: CNKI:SUN:SPCY. 0.2015-08-052

[5] Ge Xianlong, Wang Weixin. Analysis on the training of logistics innovative talents facing the strategic demand of "belt and road"[J]. Education and Teaching Forum, 2017, (34): 93-94. "In Chinese"

[6] Jiang Ling, Sun Kai. Application of task-based approach in college English teaching based on internet-assisted multimedia[J]. International Journal of Education and Management Engineering, 2012, 2(8): 58-64. DOI: https://doi.org/10.5815/ ijeme.2012.08.10

[7] Zhang Liqin, Wei Dandan, Huang Lehui. The research on the program of educational technology ability building for vocational education teachers[J]. International Journal of Education and Management Engineering, 2012, 2(11): 46-51.

[8] Deng Deai, Li Shulin. A study on the cultivation of logistics talents under the "belt and road" strategy[J]. Logistics Technology, 2016, (11): 185188. "In Chinese". DOI: https: // doi.org/ 10.3969/ j.issn. 1005- 152X.2016.11.040

[9] Yang Jie. A study on optimizing the training of higher vocational logistics personnel based on the perspective of cooperation[J]. Enterprise Logistics Technology, 2013, (7): 472-474. "In Chinese". DOI: https://doi.org/10.3969/j. issn. 1005-152X 2013.07.151

[10] Bian Hua. Curriculum reform and practice of "logistics information technology" based on project teaching method[J]. Education and Occupation, 2015, (28): 98-101. "In Chinese". DOI: https://doi. org/10.13615/j.cnki.1004-3985.2015.28.036

[11] Fatima S, Abdullah S. Improving teaching methodology in system analysis and design using problem based learning for ABET[J]. International Journal of Modern Education and Computer Science, 2013, 5(7): 60-68. DOI: https://doi. org/10.5815/ijmecs.2013.07.07

[12] Wei Xianmin. Discovery and practice of EDA experimental teaching reform[J]. International Journal of Education and Management Engineering, 2011, 1(4): 41-45. DOI: https://doi.org/10.5815/ ijeme.2011.04.07 
[13] Liu Jianjun. Research on strategies and patterns of research teaching $[\mathrm{J}]$. International Journal of Education and Management Engineering, 2012, 2(12): 67-72. DOI: https://doi.org/10.5815/ijeme. 2012.12.11

[14] Dimmock C, Tan C Y, Nguyen D, et al. Implementing education system reform: local adaptation in school reform of teaching and learning[J]. International Journal of Educational Development, 2021(80): 102-108. DOI: https:// doi.org/10.1016/j.ijedudev.2020.102302

[15] Zheng D. On the training mode of logistics management talents under the background of " $1+$ $X$ " certificate $[\mathrm{J}]$. Destech Transactions on Social Science, Education and Human Science, 2020, (17): 23-29. DOI: https://doi.org/10.12783/dtssehs/ icesd2020/34081

[16] Wang Y. Teaching reform practice of e-commerce major integrating specialty and entrepreneurship[C]. 2020 International Conference on E-Commerce and Internet Technology (ECIT), 2020: 32-35.

DOI: https://doi.org/10.1109/ECIT50008. 2020.00015

[17] Shi Yongqiang, Yang Liu, Zhang Zhiyong. Study on course teaching reform of logistics engineering specialty based on innovation capacity cultivation: in the case of theory and practice of logistics distribution course[J]. Logistics Technology, 2017, (01): 25-23.

[18] Nwokoye C, Umeh I, Mbeledogu N. GeoNaija: Enhancing the teaching and learning of geography through mobile applications $[\mathrm{J}]$. International Journal of Education and Management Engineering, 2019, 9(6): 11-24. DOI: https://doi.org/10.5815/ ijeme.2019.06.02

[19] Wang Xiaoli, Cao Zilin. Discussion reform of forestry panorama course teaching $[\mathrm{J}]$. International Journal of Modern Education and Computer Science, 2012, 12(29): 41-45. DOI: https:// doi.org/10.5815/ijeme.2012.12.07

[20] Zhang Shunli, Yin Qingshuang. Research of network teaching platform based $\operatorname{grid}[\mathrm{J}]$. International Journal of Education and Management Engineering, 2012, 2(6): 41-46. DOI: https://doi.org/10.5815/ijeme.2012.06.07

[21] Wei Bo. Research on the teaching reform of higher vocational courses of logistics system planning and design based on P-PBL[C]. 5th International Conference on Economics, 2020: 1289-1291. DOI: https://doi.org/10.2991/aebmr.k. 191225.258 